\title{
PENINGKATAN SIKAP JUJUR DAN HASIL BELAJAR MATEMATIKA MATERI TRIGONOMETRI MENGGUNAKAN PENDEKATAN SCAFFOLDING PADA PESERTA DIDIK KELAS X IPS 2 MAN 3 BOYOLALI SEMESTER GENAP TAHUN PELAJARAN 2019/2020
}

\author{
HANIAH BUDIASTUTI \\ MAN 3 Boyolali \\ Email : astuti.honey@gmail.com
}

\begin{abstract}
ABSTRAK
Penelitian ini bertujuan untuk memperbaiki proses pembelajaran dan meningkatkan kejujuran serta hasil belajar matematika peserta didik dengan pendekatan scaffolding. Jenis penelitian ini adalah Penelitian Tindakan Kelas. Penelitian ini dilaksanakan dalam dua siklus, masing-masing siklus terdiri dari 4 tahap, yaitu tahap perencanaan, pelaksanaan tindakan, pengamatan dan refleksi. Penelitian ini dilaksakan di kelas X IPS 2 MAN 3 Boyolali pada semester genap Tahun Pelajaran 2019/2020 dengan subjek penelitian 28 peserta didik. Instrumen penelitian terdiri atas perangkat pembelajaran dan instrumen pengumpulan data. Hasil penelitian menunjukkan bahwa pendekatan pembelajaran Scaffolding dapat meningkatkan kejujuran dan hasil belajar peserta didik. Pada siklus I nilai kejujuran peserta didik mencapai 60\%, dan siklus II meningkat menjadi $73 \%$. Aktivitas peserta didik dalam kegiatan pembelajaran siklus I dan II mengalami peningkatan, dari $65,7 \%$ menjadi 74,7,33\%. Selanjutnya, hasil belajar peserta didik mengalami peningkatan, pada siklus I persentase peserta didik yang tuntas sebesar $46,43 \%$ dan pada siklus II meningkat menjadi 78,57\%.
\end{abstract}

Kata Kunci: Sikap Jujur, Hasil Belajar, Scaffolding

\section{PENDAHULUAN}

Tujuan mata pelajaran matematika adalah untuk membekali peserta didik dengan kemampuan berpikir logis, analitis, sistematis, kritis, dan kreatif, serta kemampuan bekerja sama. Untuk mencapai tujuan pembelajaran tersebut, seorang guru hendaknya dapat menciptakan kondisi dan situasi yang memungkinkan peserta didik aktif menemukan, membentuk dan mengembangkan pengetahuannya. Hal ini sebagaimana dijelaskan oleh Jean Piaget, bahwa pengetahuan atau pemahaman peserta didik ditemukan, dibentuk dan dikembangkan oleh peserta didik itu sendiri (Susanto, 2015: 191).

Sumantri (1988: 42) menyatakan bahwa penalaran merupakan suatu proses berpikir dalam menarik suatu kesimpulan yang berupa pengetahuan dan mempunyai karakteristik tertentu dalam menemukan kebenaran. Peserta didik SMA kelas X merupakan peralihan dari peserta didik SMP sehingga kemampuan penalaran peserta didik kelas X masih cenderung seperti peserta didik SMP. Oleh karena itu, perlu dilakukan penelitian mengenai kemampuan penalaran matematis pada kelas $\mathrm{X}$ yang nantinya mampu meningkatkan hasil belajar matematika pada peserta didik.

Selain kemampuan penalaran matematis, peserta didik juga harus memiliki karakter yang baik. Salah satu karakter yang harus dimiliki peserta didik adalah kejujuran. Kejujuran merupakan nilai dasar yang harus dimiliki seseorang. Dalam pembelajaran matematika, kejujuran memiliki peran sangat penting, karena dapat menjadi landasan dalam mencapai tujuan pembelajaran yang ditentukan.

Kegiatan pengajaran pada mata pelajaran matematika di tingkat SMA cenderung menggunakan metode ceramah yang menyebabkan peserta didik cenderung pasif, karena sebagian waktu peserta didik hanya sebagai pendengar dan pengamat.

Materi trigonometri merupakan materi pokok pelajaran matematika kelas X pada semester genap. Materi trigonometri merupakan salah satu materi yang dianggap sulit oleh peserta didik. Penguasaan materi trigonometri di MAN 3 Boyolali masih tergolong rendah. Hal ini 


\section{SOCIAL: Jurnal Inovasi Pendidikan IPS \\ Vol. 1 No. 2 September 2021, e-ISSN : 2797-8842 | p-ISSN : 2797-9431}

ditunjukkan pada hasil belajar matematika yang masih rendah pada tahun pelajaran 2018/2019 pada penguasaan Trigonometri.

Hasil belajar yang baik perlu didukung dengan pemberian bantuan kepada peserta didik. Scaffolding merupakan pemberian bantuan kepada peserta didik secara bertahap Rendahnya hasil belajar peserta didik ini dilihat dari nilai peserta didik yang masih di bawah KKM dan belum mencapai ketuntasan minimal klasikal. Hal ini dapat diketahui dari hasil pembelajaran siswa saat pembelajaran bahwa sebantak 16 peserta didik $(61,53 \%)$ tidak tuntas pada materi trigonometri, dan sebanyak 10 peserta didik $(38,47 \%)$ sudah tuntas pada materi trigonometri. Oleh karena itu dapat disimpulkan bahwa ketuntasan belajar peserta didik secara klasikal untuk tahun pelajaran 2018/2019 belum tuntas karena masih di angka 38,48\%.sampai peserta didik dapat bertanggung jawab. Bantuan dalam scaffolding tidak hanya dari guru tapi juga dari orang dewasa atau teman yang lebih mengerti. Menurut Kurniasih (2012:118) dalam pembelajaran scaffolding guru memberikan bantuan belajar secara penuh dan kontinu, dalam hal ini scaffolding untuk membantu peserta didik membangun pemahaman atas pengetahuan dan proses yang baru. Dengan adanya bantuan scaffolding diharapkan peserta didik dapat memahami materi dengan baik dan saling membantu dan bertukar pengetahuan dengan peserta didik lainnya.

Berdasarkan uraian di atas, alasan peneliti memilih pendekatan scaffolding dalam pembelajaran trigonometri karena ingin mengetahui pengaruh dari pendekatan tersebut dalam meningkatkan hasil belajar dan kejujuran peserta didik.

Seseorang dikatakan belajar matematika apabila pada dirinya terjadi suatu kegiatan yang mengakibatkan perubahan tingkah laku yang berkaitan dengan matematika. Belajar matematika merupakan suatu aktivitas mental untuk memahami konsep dalam matematika yang kemudian diterapkan kedalam situasi lain. Hasratuddin mengutip pendapat Schoenfeld bahwa learning mathematics is doing mathematics, yang berarti bahwa belajar matematika adalah menyelesaikan masalah. Secara umum, dikatakan bahwa dalam menyelesaikan setiap masalah matematis selalu berdasar pada konsep-konsep, prosedur-prosedur, strategi berpikir, motivasi, empati dan dorongan emosi, sehingga menghasilkan kesimpulan dan tindakan yang logis (Hasratuddin, 2015: 146).

Cronbach berpendapat bahwa learning is shown by change in behavior as a result of experience. Belajar adalah suatu aktivitas yang ditunjukkan oleh perubahan tingkah laku sebagai hasil dari pengalaman.

Gagne mengungkapkan bahwa belajar merupakan kegiatan kompleks. Setelah belajar orang memiliki ketrampilan, pengetahuan, sikap dan nilai. Timbulnya kapabilitas tersebut dari stimulasi yang berasal dari lingkungan dan proses kognitif yang dilakukan oleh pebelajar (Mudjiono \& Dimyati, 2002:10).

Hasil belajar merupakan perubahan tingkah laku secara keseluruhan yang dimiliki seseorang. Perubahan yang terjadi itu sebagai akibat dari kegiatan belajar yang telah dilakukan oleh individu. Perubahan itu adalah hasil yang telah dicapai dari proses belajar. Jadi untuk mendapatkan hasil belajar dalam bentuk perubahan harus melalui proses tertentu yang dipengaruhi oleh faktor dari dalam diri individu dan diluar individu (Djamarah, S. B., 2008: 175).

Faktor-faktor yang mempengaruhi belajar banyak jenisnya, tetapi dapat digolongkan menjadi dua golongan saja yaitu faktor eksternal dan faktor internal. Faktor eksternal adalah faktor yang ada diluar individu sedangkan faktor internal adalah faktor yang berasal dari dalam diri individu (Djamarah, S. B., 2008: 177-205).

Scaffolding merupakan interaksi antara pendidik dan peserta didik dengan tujuan untuk membantu peserta didik yang mengalami kesulitan dalam proses pembelajaran guna meningkatkan pemahaman dan keterampilan peserta didik (Badriyah, Abdur, \& Hery, 2017: 50). Pemberian Scaffolding dilakukan secara bertahap dan akan dikurangi seiring dengan meningkatnya pengetahuan peserta didik (Rusli, M. A. \& Wahono, W., 2014: 1-11). Bantuan yang diberikan berupa petunjuk, peringatan, dorongan, menguraikan masalah ke dalam bentuk 
lain yang memungkinkan peserta didik dapat mandiri dan menyelesaikan tugas (Ashari, Salwa, \& Fitriani, 2016: 25).

Ashari, Salwah, \& Fitriani, 2016: 26 menyebutkan bahwa langkah-langkah strategi pembelajaran scaffolding sebagai berikut:

a) Mengecek pengetahuan sebelumnya yang dimiliki oleh peserta didik.

b) Menentukan the Zone of Proximal Development (ZPD) untuk masing-masing peserta didik, kemudian dapat dikelompokkan menurut level perkembangan awal yang dimiliki.

c) Merancang tugas-tugas belajar (aktivitas belajar scaffolding).

d) Memantau aktifitas dalam belajar.

e) Mengecek dan mengevaluasi belajar.

\section{METODE PENELITIAN}

Penelitian ini menggunakan Penelitian Tindakan Kelas (classroom action research). PTK yaitu suatu bentuk kajian yang bersifat reflektif oleh pelaku tindakan, yang dilakukan untuk meningkatkan kemantapan rasional dari tindakan-tindakan mereka dalam melaksanakan tugas, memperdalam pemahaman terhadap tindakan-tindakan yang dilakukan itu, memperbaiki kondisi dimana praktik-praktik pembelajaran tersebut dilakukan, serta dilakukan secara kolaboratif (Saminanto, 2010: 2). Arikunto (2009: 20) menyatakan ada empat tahapan penting dalam penelitian tindakan kelas yaitu (1) perencanaan, (2) pelaksanaan,(3) pengamatan dan (4) refleksi.

Penelitian Tindakan Kelas dilakukan di MAN 3 Boyolali, Jl. Gading, Jenengan, Sawit, Boyolali Jawa Tengah pada tanggal 27 Januari s.d. 14 Maret 2020 (Semester GenapTahun Pelajaran 2019/2020). Subjek penelitian adalah peserta didik kelas X IPS 2 MAN 3 Boyolali Tahun Pelajaran 2019/2020 dengan jumlah 28 peserta didik.

\section{HASIL DAN PEMBAHASAN}

\section{Penerapan Pendekatan Scaffolding}

Berdasarkan kegiatan pembelajaran matematika materi trigonometri di MAN 3 Boyolali dengan menggunakan pendekatan scaffolding selama siklus I dan siklus II menujukkan bahwa model pembelajaran tersebut mampu meningkatkan aktivitas peserta didik pada saat pembelajaran.

Salah satu kelebihan dari pendekatan scaffolding yaitu meningkatkan belajar melalui interaksi sosial dengan melibatkan pemahaman, dan kebutuhan belajar. Peserta didik yang membutuhkan scaffolding dengan intensitas tinggi akan lebih banyak berinteraksi dengan pendidik sehingga, komunikasi yang baik akan terbangun (Rahmatiah, Koes, \& Kusairi, 2016: 45-54). Selain itu pendekatan scaffolding juga mampu membantu peserta didik yang mengalami kesulitan dalam proses pembelajaran guna meningkatkan pemahaman dan keterampilan peserta didik (Ashari, Salwa, \& Fitriani, 2016: 25).

Peningkatan aktivitas peserta didik pada saat pembelajaran di siklus I dan siklus II dapat dilihat pada Tabel 1 dan Gambar 1 di bawah ini:

Tabel 1. Hasil Pengamatan Aktivitas Peserta Didik Selama Kegiatan Pembelajaran Pada Siklus I Dan II

\begin{tabular}{|l|c|c|}
\hline \multicolumn{1}{|c|}{ Indikator } & Siklus I & Siklus II \\
\hline Kehadiran peserta didik & $96 \%$ & $100 \%$ \\
\hline $\begin{array}{l}\text { Perhatian peserta didik } \\
\text { terhadap penjelasan materi }\end{array}$ & $59 \%$ & $71 \%$ \\
\hline $\begin{array}{l}\text { Keaktifan peserta didik } \\
\text { dalam bertanya }\end{array}$ & $58 \%$ & $66 \%$ \\
\hline $\begin{array}{l}\text { Ketepatan dalam } \\
\text { mengerjakan LKPD }\end{array}$ & $64 \%$ & $70 \%$ \\
\hline
\end{tabular}


Vol. 1 No. 2 September 2021, e-ISSN : 2797-8842 | p-ISSN : 2797-9431

\begin{tabular}{|l|c|c|}
\hline $\begin{array}{l}\text { Mempresentasikan hasil } \\
\text { diskusi kelompok }\end{array}$ & $57 \%$ & $73 \%$ \\
\hline $\begin{array}{l}\text { Membuat kesimpulan tentang } \\
\text { materi yang di pelajari }\end{array}$ & $61 \%$ & $68 \%$ \\
\hline Rata Rata & $65,7 \%$ & $74,7 \%$ \\
\hline
\end{tabular}

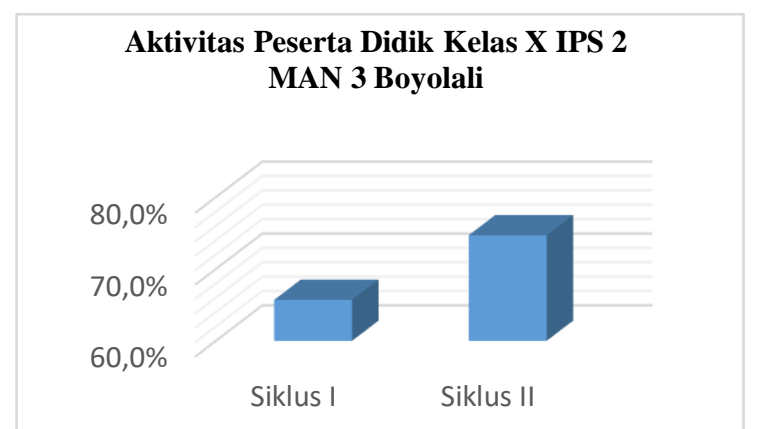

\section{Gambar 1. Hasil Observasi Aktivitas Peserta Didik Secara Individual Sumber: Dokumentasi Guru.}

Berdasarkan diagram diatas, terjadi peningkatan aktivitas peserta didik selama siklus I dan siklus II. Pada siklus I nilai rata-rata yang diperoleh berdasarkan observasi aktivitas peserta didik yaitu sebesar 65,7 kemudian pada siklus II meningkat menjadi 74,7.

Pada siklus I menunjukkan bahwa kegiatan pembelajaran menggunakan pendekatan scaffolding mendapatkan skor persentase rata-rata 65,7\% (kategori baik). Namun, masih terdapat beberapa aktivitas yang perlu ditingkatkan yaitu perhatian peserta didik terhadap penjelasan materi, keaktifan peserta didik dalam bertanya, dan keaktifan mempresentasikan hasil diskusi kelompok. Sehingga peserta didik dapat dikatakan kurang aktif, seperti yang dikemukakan oleh Rohani, 2004: 19 bahwa peserta didik aktif adalah peserta didik yang aktif dengan anggota badan, membuat sesuatu, bermain atau bekerja, ia tidak hanya duduk dan mendengar. Maka guru harus lebih memperhatikan setiap peserta didik agar aktif dalam proses pembelajaran.

Pada siklus II aktivitas peserta didik mengalami peningkatan dengan kriteria baik dengan persentase nilai rata-rata $74,7 \%$. Hal-hal yang mengalami peningkatan yaitu perhatian peserta didik terhadap penjelasan materi, keaktifan peserta didik dalam bertanya, dan keaktifan mempresentasikan hasil diskusi kelompok. Hal ini menunjukkan bahwa dengan menggunakan pendekatan scaffolding aktivitas peserta didik dalam proses pembelajaran terus meningkat.

Peningkatan kejujuran peserta didik dalam kelompok dapat dilihat pada Tabel 2 Dan Gambar 2 berikut:

Tabel 2. Hasil Pengamatan Kejujuran Peserta Didik Pada Kondisi Awal, Siklus I Dan Siklus II 
Vol. 1 No. 2 September 2021, e-ISSN : 2797-8842 | p-ISSN : 2797-9431

\begin{tabular}{|l|c|c|c|}
\hline Indikator & Awal & Siklus I & Siklus II \\
\hline $\begin{array}{l}\text { Menyampaikan } \\
\text { sesuatu sesuai } \\
\text { dengan keadaan yang } \\
\text { sebenarnya }\end{array}$ & $60 \%$ & $67 \%$ & $72 \%$ \\
\hline $\begin{array}{l}\text { Bersedia mengakui } \\
\text { kesalahan, } \\
\text { kekurangan, ataupun } \\
\text { keterbatasan dirinya }\end{array}$ & $61 \%$ & $71 \%$ & $73 \%$ \\
\hline $\begin{array}{l}\text { Tidak suka } \\
\text { mencontek suka }\end{array}$ & $47 \%$ & $50 \%$ & $70 \%$ \\
\hline $\begin{array}{l}\text { Tidak } \\
\text { berbohong }\end{array}$ & $51 \%$ & $55 \%$ & $70 \%$ \\
\hline $\begin{array}{l}\text { Tidak memanipulasi } \\
\text { fakta/ informasi }\end{array}$ & $47 \%$ & $57 \%$ & $78 \%$ \\
\hline Rata-rata & $53 \%$ & $60 \%$ & $73 \%$ \\
\hline
\end{tabular}

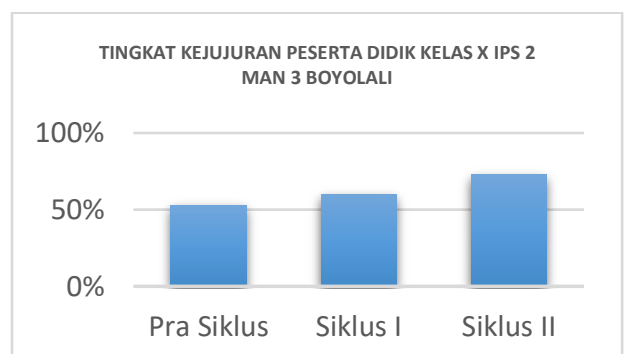

\section{Gambar 2. Tingkat Kejujuran Peserta Didik \\ Sumber: Dokumentasi Guru.}

Pada pra siklus nilai rata-rata tingkat kejujuran peserta didik 53\%, siklus I hasil pengamatan kejujuran peserta didik rata-rata tingkat sebesar $60 \%$. Terdapat tiga aspek yang harus diperbaiki terutama masih banyaknya peserta didik yang menyalin atau menyontek pekerjaan orang lain. Serta, masih banyak peserta didik yang belum mandiri dalam mengerjakan tugas dan masih banyak membutuhkan bantuan dalam menyelesaikan tugas yang diberikan oleh guru.

Pada siklus II hasil pengamatan kejujuran peserta didik meningkat menjadi 73\%. Untuk indikator kemandirian peserta didik dalam mengerjakan tugas tanpa bantuan orang lain menunjukan kriteria sangat baik di angka $78 \%$. Selanjutnya, untuk jumlah peserta didik yang mencontek saat mengerjakan tugas juga sudah berkurang.

Berdasarkan hasil observasi tingkat kejujuran peserta didik selama proses pembelajaran dengan penerapan pendekatan scaffolding pada siklus I dan siklus II menunjukkan bahwa kejujuran peserta didik mengalami peningkatan.

\section{Aktivitas Guru Selama Proses Pembelajaran}

Guru yang mengelola pembelajaran dengan menggunakan pendekatan scaffolding, dalam penelitian ini adalah peneliti sendiri yang menjadi guru dan yang menjadi pengamat adalah salah satu guru bidang studi Matematika di MAN 3 Boyolali. Pada siklus I pada aktivitas guru dalam mengelola pembelajaran masih dalam kategori cukup dengan persentase nilai $65,33 \%$. Namun, ada beberapa kemampuan yang masih kurang. Pertama, kemampuan memotivasi peserta didik dalam mengaitkan pengalaman pribadi peserta didik dalam kehidupan sehari-hari dengan materi yang akan dipelajari. Kedua, kemampuan mendorong peserta didik 
untuk bertanya. Ketiga, kemampuan guru mengarahkan peserta didik untuk menarik kesimpulan tentang materi yang dipelajari.

Pada siklus II mengalami peningkatan dari kategori cukup menjadi sangat baik dengan persentase nilai $81,33 \%$. Aktivitas yang meningkat pada siklus II yaitu kemampuan guru mengarahkan peserta didik untuk menarik kesimpulan tentang materi yang dipelajari.

Dapat disimpulkan bahwa aktivitas guru dalam pengelolaan pembelajaran dengan pendekatan scaffolding pada materi trigonometri meningkat dari cukup, baik dan baik sekali. Hal ini disebabkan karena aktivitas guru dalam melaksanakan pembelajaran pada kegiatan awal, inti dan akhir sudah terlaksana sesuai dengan RPP.

\section{Hasil Belajar Peserta Didik}

Berdasarkan data awal hasil belajar peserta didik di kelas X IPS 2 MAN 3 Boyolali yaitu dari 28 peserta didik, baru sebesar $28,57 \%$ peserta didik mendapat nilai diatas KKM dan $71,43 \%$ peserta didik mendapat nilai dibawah KKM. Hal ini terjadi karena pembelajaran yang dilakukan oleh guru masih menggunakan metode konvensional dengan mengutamakan ceramah dari pada keaktifan peserta didik dalam belajar. Data awal hasil belajar peserta didik di kelas X IPS 2 dapat dilihat pada Tabel 3 dan Gambar 3 berikut.

Tabel 3. Hasil Peningkatan Hasil Belajar Pada Kondisi Awal Peserta Didik Kelas X IPS 2

\begin{tabular}{|l|c|}
\hline \multicolumn{1}{|c|}{ Hasil Belajar } & Kondisi Awal \\
\hline Nilai Tertinggi & 85 \\
\hline Nilai Terendah & 23 \\
\hline Nilai Rata-rata & 66,64 \\
\hline Rentang & 62 \\
\hline Tuntas & $8(28,57 \%)$ \\
\hline Tidak Tuntas & $20(71,43 \%)$ \\
\hline
\end{tabular}

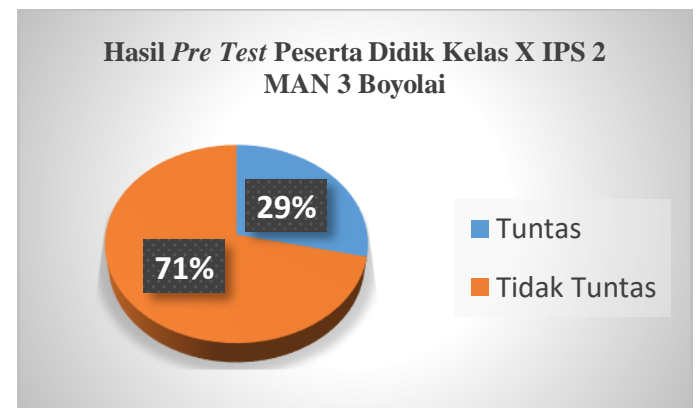

\section{Gambar 3. Data Kondisi Awal hasil belajar peserta didik di kelas X IPS 2 Sumber: Dokumentasi Guru}

Setelah diterapkan pendekatan scaffolding pada pembelajaran matematika materi trigonometri, hasil belajar yang dimiliki peserta didik kelas X IPS 2 MAN 3 Boyolali mengalami peningkatan pada siklus I dan siklus II.

Peningkatan ini terjadi karena seperti yang dikemukakan oleh Roebiyanto \& Harmini, 2017: 37, terdapat empat langkah penyelesaian masalah yaitu memahami masalah, memilih strategi, melaksanakan strategi, melaksanakan strategi, dan memeriksa kembali. Sebelum pendekatan scaffolding diterapkan peserta didik sulit untuk memahami materi pelajaran karena pembelajaran yang didominasi oleh guru dan menjadikan peserta didik pasif sehingga hasil belajar yang dimiliki peserta didik menjadi rendah. Pendekatan scaffolding mampu membantu peserta didik yang mengalami kesulitan dalam proses pembelajaran guna meningkatkan pemahaman dan keterampilan peserta didik (Ashari, Salwa, \& Fitriani, 2016: 25). 
Pada siklus I persentase hasil belajar yang dimiliki peserta didik meningkat menjadi $53,57 \%$ peserta didik mendapat nilai dibawah KKM dan 46,43\% peserta didik mendapat nilai diatas KKM. Sedangkan pada siklus II persentase hasil belajar yang dimiliki peserta didik mendingkat lagi menjadi 78,6\% peserta didik mendapat nilai diatas KKM dan 21,4\% peserta didik mendapat nilai dibawah KKM. Data tersebut dapat digambarkan dalam Tabel 4 dan Gambar 4. dibawah ini:

Tabel 3. Hasil Peningkatan Hasil Belajar Siswa Pada Kondisi Awal, Siklus I dan Siklus

\begin{tabular}{|l|l|l|l|}
\hline \multicolumn{5}{|l}{ II } \\
\hline Hasil Belajar & Kondisi Awal & Siklus I & Siklus II \\
\hline Nilai Tertinggi & 85 & 82,5 & 90 \\
\hline Nilai Terendah & 23 & 47,5 & 72,5 \\
\hline Nilai Rata-rata & 66,64 & 69,9 & 77,5 \\
\hline Rentang & 62 & 35 & \\
\hline Tuntas & $8(28,57 \%)$ & $13(46,43 \%)$ & $22(78,57 \%)$ \\
\hline Tidak Tuntas & $20(71,43 \%)$ & $15(53,57 \%)$ & $6(21,43 \%)$ \\
\hline
\end{tabular}

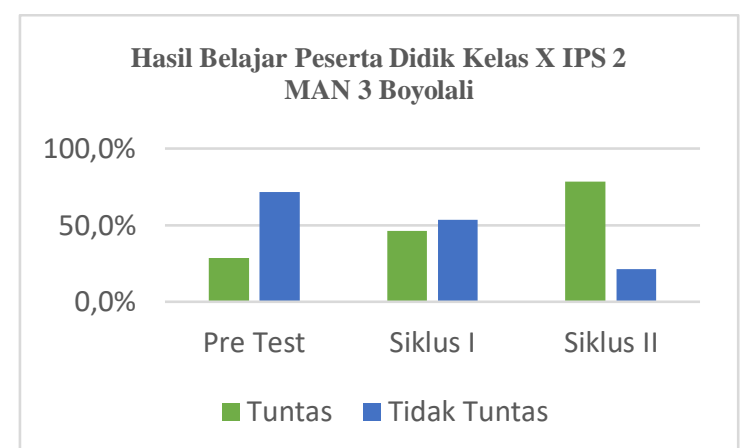

\section{Gambar 4. Hasil Belajar Peserta Didik Kelas X IPS 2 MAN 3 Boyolali} Sumber: Dokumentasi Guru.

Berdasarkan Tabel 4 dan Gambar 4. persentase hasil belajar yang dimiliki peserta didik pada pra penelitian ke siklus I sudah mengalami peningkatan, namun masih belum memenuhi ketuntasan klasikal yaitu 75\%. Hal ini diketahui berdasarkan hasil tes Siklus I bahwa sebantak 15 peserta didik $(53,57 \%)$ tidak tuntas pada materi trigonometri, dan sebanyak $13(46,42 \%)$ sudah tuntas pada materi trigonometri. Oleh karena itu dapat disimpulkan bahwa ketuntasan belajar peserta didik secara klasikal untuk siklus I belum tuntas karena masih diangka 46,43\%.

Kemudian setelah siklus I peneliti mengadakan perbaikan berdasarkan kekurangan yang terjadi di siklus I untuk diterapkan pada siklus II. Perbaikan yang dilakukan peneliti yaitu ketika siklus I terutama pada tahap belum terbiasanya peserta didik dengan pembelajaran scaffolding, ketika peserta didik diminta untuk menanggapi pertanyaan dari teman atau guru, mereka cenderung diam dan malu untuk mengutarakan jawaban, sehingga terlihat kurang percaya diri yang menimbulkan sikap ketidakjujuran peserta didik, sehingga pendekatan pembelajaran scaffolding tidak terlaksana sesuai yang diharapan.

Kemudian setelah dilakukan perbaikan perbaikan pada pelaksanaan siklus II presentase hasil belajar peserta didik mengalami peningkatan yaitu menjadi 78,6\% peserta didik yang mendapat nilai di atas KKM begitu pula pada tingkat kejujuran peserta didik telah meningkat mencapai di atas KKM yaitu $76 \%$, sehingga setelah siklus II tidak diadakan siklus lanjutan karena sudah memenuhi indikator ketuntasan klasikal sebesar $75 \%$. 


\section{KESIMPULAN}

Hasil penelitian tindakan kelas (PTK) ini dapat disimpulkan sebagai berikut:

1. Penerapan pendekatan scaffolding pada pembelajaran matematika materi trigonometri menunjukkan hasil yang sangat baik. Hal ini dapat dilihat dari hasil observasi aktivitas peserta didik pada saat tahap pelaksanaan tidakan. Pada siklus I nilai aktivitas peserta didik mencapai $65,7 \%$ (baik), kemudian dilakukan perbaikan di siklus II dan hasilnya menjadi $74,7 \%$ (baik). Kemudian, untuk tingkat kejujuran peserta didik dalam mengerjakan tugas pada siklus I mencapai 60\% (baik), dan dilakukan perbaikan di siklus II hasilnya meningkat menjadi 73\% (baik). Selanjutnya, Aktivitas guru dalam mengelola pembelajaran dengan pendekatan scaffolding pada siklus I dan II mengalami peningkatan. Dari 65,33\% (cukup) menjadi 81,33\% (sangat baik).

2. Hasil belajar peserta didik mengalami peningkatan setelah diterapkan pendekatan scaffolding pada pembelajaran matematika materi trigonometri. Hal ini ditunjukkan berdasarkan data siklus I, nilai rata-rata hasil belajar peserta didik mencapai 69,9 dengan persentase peserta didik yang tuntas sebesar $46,43 \%$. Setelah dilakukan perbaikan dari kekurangan yang terjadi di siklus I, nilai rata-rata hasil belajar peserta didik pada siklus II meningkat menjadi 77,6 dengan persentase peserta didik yang tuntas sebesar 78,57\%.

\section{DAFTAR PUSTAKA}

Ahmad Susanto. (2015). Teori Belajar dan Pembelajaran di Sekolah Dasar. Jakarta: Kencana Predana Media Group.

Dimyati \& Mudjiono. (2002). Belajar dan Pembelajaran. Jakarta: Rineka Cipta.

Djamarah, Syaiful Bahri. (2008). Psikologi Belajar. Jakarta: Rineka Cipta.

Kurniasih, A.W. (2012). Scaffolding sebagai Alternatif Upaya Meningkatkan Kemampuan Berpikir Kritis Matematika. Jurnal Unnes. Vol. 3 No.2:113-124.

Lailatul Badriyah, Abdur Rahman \& Hery Susanto. (2017). Analisis Kesalahan Dan Scaffolding Siswa Berkemampuan Rendah Dalam Menyelesaikan Operasi Tambah Kurang Bilangan Bulat. Jurnal Pendidikan: Teori Penelitian Dan Pengembangan, 2.1: 50.

Muhammad Aqil Rusli and Wahono Widodo. (2014). Pembelajaran Fisika Melalui Pemrosesan Top Down Berbasis Scaffolding Untuk Melatihkan Keterampilan Berpikir Kritis. Physics Learning through Top Down Processing Based on Scaffolding to Train Critical Thinking Skills. III.1: 1-11.

Nur Wahidin Ashari, Salwah and Fitriani A. (2016). Implementasi Strategi Pembelajaran Scaffolding Melalui Lesson Study Pada Mata Kuliah Analisi Real. Jurnal Matematika Dan Pendidikan Matematika, 1.1: 25.

Saminanto. (2010). Ayo Praktik PTK. Semarang : Rasail Media Group.

Sumantri, Jujun S. (1988). Filsafat Ilmu Sebuah Pengantar Populer. Jakarta: Sinar Harapan. 